\title{
The Missing Link in the Realization of the African Integrated High-Speed Railway Network: Rules on Technical Standards and Operation
}

\author{
Said Nyambu Rajab
}

\begin{abstract}
One of the major objectives of the African Union (AU) is to develop an integrated high-speed railway network connecting major African cities for improved continental trade and competition. This paper provides an overview of the main technical aspects of railway lines with special focus on crossborder operational and technical interoperability. It briefly describes the missing link in realizing a truly interoperable high-speed railway lines network for the African case. It introduces the technical aspects of railway lines that must be unified for cross-border operation. It also outlines the reasons that may explain the global success of the European Rail Traffic Management System (ERTMS), offering the author's view on factors that continue to influence decision making in favor of ERTMS over other national and not interoperable solutions such as the Chinese Train Control System (CTCS). The paper concludes by suggesting the way forward for combined continental effort to realize the African Integrated High-Speed Railway Lines Network as part of the African Union's Agenda 2063.
\end{abstract}

Index Terms-Cross-border; ERTMS; high-speed; interoperability.

\section{INTRODUCTION}

The African Integrated High-Speed Railway Network is a flagship project spearheaded by the African Union as part of the continental Agenda 2063 [1]. The main objective is to connect Africa's capital cities and major commercial hubs with an interoperable high-speed railway lines network to boost continental trade and competition. The viability, reliability and sustainability of this project will largely depend on the extent to which its development is linked to the planning, construction (or upgrading) and operation of new or existing national and regional railway lines, electric power supply and communication infrastructure facilities [2].

Railways are characterized by technical aspects such as traction supply, rolling stock's design, train control system, track gauge, and loading gauge. The conventional railways in Africa operate on different features with regard to these technical aspects. Upgrading these railway lines for an integrated high-speed operation requires the standardization of these technical aspects. The lack of common rules on technical standards of construction and operation in Africa poses a major obstacle to the development of an integrated high-speed railway lines network as part of the African

Published on April 6, 2019.

S. N. Rajab is with the African Railway Center of Excellence of Addis Ababa Institute of Technology, Addis Ababa University, Addis Ababa, Ethiopia (rajabsaid2@gmail.com).
Union's Agenda 2063.

\section{High-SPEed Railway IN AFRICA}

While there is no standard definition of high-speed railway lines, historically, high-speed railway development has followed two primary paths to achieve high speeds: getting higher speeds on specially upgraded 'conventional' lines, or getting higher speeds on new 'dedicated highspeed' lines. High-speed trains include those operating on 'conventional' lines at speeds of up to $200 \mathrm{~km} / \mathrm{h}$ and those operating on 'dedicated high-speed' lines at speeds of 200 to $350 \mathrm{~km} / \mathrm{h}$ [3]. Most of the high-speed railway services and track are primarily or exclusively for passenger trains. Over the years, various manufacturers have put together their expertise to develop and implement high-speed train principles.

On 15th November 2018, Morocco became the first country in Africa to open a high-speed railway line for passenger operation. The 323-km Tangier - Casablanca railway line has an operational speed of $320 \mathrm{~km} / \mathrm{h}$ on the 186-km dedicated high-speed line between Tangier and Kenitra and $160 \mathrm{~km} / \mathrm{h}$ on the $137-\mathrm{km}$ conventional track section between Kenitra and Casablanca [4].

\section{PRESENT SCENARIo ON SignALING TRAIN CONTROL SYSTEMS}

Over the years, different train control systems (see Error! Reference source not found.) have been installed on Africa's railway lines and operated by individual railway operators according to their national requirements on technical standards and operating rules. Today, trains in Africa are equipped with different train control systems and railway lines have different gauges. A train crossing from one African country to another must switch the operating standards as it crosses the border. This leads to loss of time at the border due to formalities. Even within the same country, a train may have to be equipped with more than one control system because of the need to switch from, say, European operating standard to Chinese standard. A 'good' example is Ethiopia; the Addis Ababa - Djibouti railway line has been equipped with the Chinese Train Control System (CTCS), while the Awash - Woldiya line will be equipped with the European Train Control System (ETCS). As such, the two railway lines are not interoperable - 'an Addis Ababa - Djibouti train' must at least be equipped with the ETCS onboard subsystem to run safely on the Awash - Woldiya line as well. 
TABLE I: TECHNICAL ASPECTS OF SELECTED RAILWAYS IN AFRICA

\begin{tabular}{lll}
\hline \hline $\begin{array}{l}\text { Line } \\
\text { (Country) }\end{array}$ & $\begin{array}{l}\text { Gauge \& Traction } \\
\text { Power }\end{array}$ & $\begin{array}{l}\text { Control } \\
\text { System }\end{array}$ \\
\hline $\begin{array}{l}\text { Mombasa - Nairobi } \\
\text { (Kenya) }\end{array}$ & $1435 \mathrm{~mm}$; diesel & CTCS L 2 \\
$\begin{array}{l}\text { Dar es Salaam - Morogoro } \\
\text { (Tanzania) }\end{array}$ & $1435 \mathrm{~mm} ; 25 \mathrm{kV} \mathrm{AC}$ & ETCS L 2 \\
$\begin{array}{l}\text { Addis Ababa - Djibouti } \\
\begin{array}{l}\text { Awash - Woldiya } \\
\text { (Ethiopia) }\end{array}\end{array}$ & $1435 \mathrm{~mm} ; 25 \mathrm{kV} \mathrm{AC}$ & CTCS L 2 \\
$\begin{array}{l}\text { Chingola - Livingstone } \\
\text { (Zambia) }\end{array}$ & $1067 \mathrm{~mm}$; diesel & ETCS L 1 \\
$\begin{array}{l}\text { Abuja - Kaduna } \\
\begin{array}{l}\text { Itakpe-Ajaokuta-Warri } \\
\text { (Nigeria) }\end{array}\end{array}$ & $1435 \mathrm{~mm}$; diesel & CTCS L 2 \\
$\begin{array}{l}\text { Tangier - Kenitra } \\
\text { Kenitra - Casablanca } \\
\text { (Morocco) }\end{array}$ & $1435 \mathrm{~mm}$; 25 kV AC & ETCS L 2 \\
$\begin{array}{l}\text { Oued Tlelat - Tlemcen } \\
\text { (Algeria) }\end{array}$ & $1435 \mathrm{~mm}$; 25 kV AC & ETCS L 1 \& 2 \\
\hline \hline $\begin{array}{l}\text { Source: Own study } \\
\text { Sour }\end{array}$ & & ETCS L 2 \\
\hline
\end{tabular}

Existing signaling train control systems in Africa are national or 'stand-alone' and not interoperable, and therefore require extensive integration and engineering effort, thus raising the total delivery costs for cross-border rail traffic. This situation also creates technical barriers to international journeys, restricts competition, and hampers the envisaged competitiveness of the African railway sector vis-à-vis road transport. With such not interoperable systems, trainsets running, for instance, between Mombasa port (Kenya) and Abuja (Nigeria) may have to be equipped with different types of signaling train control systems, which brings considerable costs. Sometimes, it may even require changing the drivers at borders as each country has its own signaling system and rules for which the drivers have to be certified.

An integrated railway lines network requires crossborder ${ }^{1}$ interoperability and same safety level of railway traffic management systems. With a standardized signaling train control and safety system, the concept of interoperability can be extended to all railway lines, i.e. both high-speed lines and conventional lines where a train is equipped to run on the existing national signaling system. For interoperability to be achieved the following functions of the signaling train control system must be standardized: on-board functions to ensure that every train reacts to data received from track-side equipment in a predefined manner; track-side functions for processing data from national signaling systems and to translate such data into standard messages for the trains onboard systems; and interfaces for unidirectional or bidirectional communication between the train and track-side equipment. For interoperability to be achieved, the information displayed on the Driver Machine Interface (DMI) and the interactions between the driver and the onboard subsystem must allow the same driver to operate trains safely on cross-border railway lines (for instance, a Kenyan driver can safely drive the same train on Ethiopian, Tanzanian or Moroccan railway infrastructure).

As a key component in an integrated and fully

1 The term border in cross-border implies border between two countries, or a border between two different railway signaling systems interoperable railway lines network, a standardized signaling train control and safety system needs special focus in order to realize the African Union's Agenda 2063 of an African integrated high-speed railway network. With the recent urge for railway projects uptake, this standard should be agreed upon and rolled out as soon as possible so as to give a continental direction for the unification of the railway network. It would be a huge loss to a country that installs a national signaling train control system in 2060 and in three years phase it out for a continental standard signaling control system. The journey therefore starts now!

\section{RAILWAY POWER SUPPLY}

The railway catenary power supply is an integrated system that powers the train. It consists of high-voltage (HV) power lines, traction substations, sectioning points, overhead contact lines, pantograph, and return current circuit. Various aspects of the system must be evaluated for the electric traction system to provide interoperability: electrification system, overhead contact lines and pantographs, interaction of pantographs and overhead line equipment, and boundary between high-speed lines and conventional lines.

Trains need to be supplied with high power at minimum losses. Globally, the most preferred electrification system is $25 \mathrm{kV} 50 \mathrm{~Hz}$ AC, which is supplied directly from the highvoltage public utility network at industrial loads frequency (increased voltage means decreased current, hence reduced resistive losses). For fully compatible systems, the power supply system has to be designed such that every train in any country will be supplied with adequate power (the quality of the power collection and voltage to the train during operation must be guaranteed). To minimize power consumption, trains use regenerative braking which sends back energy to the power supply system. Therefore, every country's traction power supply system should at least be receptive to regenerative energy.

To realize fully compatible power supply systems, the geometry of the overhead contact system and of the pantographs is an important aspect that must be harmonized through a geometry standard specifying the height of the contact wire above the rails, lateral displacement, and the contact force. The geometry of the pantograph head must guarantee correct mechanical interaction with the contact wire for maximum power collection at rated speed. The electrical design must guarantee high levels of reliability, availability during operation, and high maintainability and management of the electrical installations.

Without rules and guidelines governing the development of the railway power supply system in Africa, achieving an interoperable railway network is unrealistic.

\section{ROLLING STOCK}

For railway interoperability, also rolling stock must be compatible with different power supply, signaling and train control systems. This allows cross-border operation on both AC- and DC- powered lines for true pan-continental interoperability. If different power supply systems are to be maintained, their demands would mean that each train has at least two pantographs for AC or DC power collection. In 
addition to the $25 \mathrm{kV} 50 \mathrm{~Hz} \mathrm{AC}, 750 \mathrm{~V} \mathrm{DC}, 1.5 \mathrm{kV}$ DC or 3 $\mathrm{kV} \mathrm{DC}$ might be used and this means the trains have to be tri-voltage or quad-voltage for them to operate on the different power systems. For instance, the Morocco highspeed trains are equipped to operate on both the $25 \mathrm{kV} 50$ $\mathrm{Hz}$ AC system used on the new dedicated high-speed line and $3 \mathrm{kV}$ DC system on the conventional line.

Long passenger trains might also have two pairs of pantographs, two for AC use and two for DC. When passing between areas of different supply voltage, marker boards remind the driver to turn off power, lower the pantograph(s), adjust a switch to select the appropriate system, and raise the pantograph(s). The trains must accommodate different overhead catenaries — regular height, higher and lower height. Pantograph height control is selected automatically based on the voltage system chosen by the driver. Once the train detects the correct supply, a dashboard indicator illuminates and the driver can switch on the traction motors. The train coasts across the boundary between sections.

TABLE II: EXAMPLES OF HIGH-SPEED TRAIN TECHNOLOGIES

\begin{tabular}{|c|c|c|}
\hline Technology & Speed $(\mathrm{km} / \mathrm{h})$ & Technical features \\
\hline $\begin{array}{l}\text { Bombardier's } \\
\text { ZEFIRO V30O }\end{array}$ & 380 & $\begin{array}{l}\text { Normal motor bogie design ( } 2 \\
\text { bogies on both sides of the car). } \\
\text { Signaling: ERTMS }\end{array}$ \\
\hline $\begin{array}{l}\text { Siemens' } \\
\text { Velaro }\end{array}$ & 360 & $\begin{array}{l}\text { Normal motor bogie design ( } 2 \\
\text { bogies on both sides of the car). } \\
\text { Signaling: ERTMS }\end{array}$ \\
\hline $\begin{array}{l}\text { Alstom's } \\
\text { Avelia }\end{array}$ & 350 & $\begin{array}{l}\text { Jacobs bogie configuration ( } 2 \\
\text { cars sharing the same bogie). } \\
\text { Signaling: TVM- } 430 \text { / ERTMS }\end{array}$ \\
\hline $\begin{array}{l}\text { Japanese E5 } \\
\text { Shinkansen }\end{array}$ & 320 & $\begin{array}{l}\text { Normal motor bogie design ( } 2 \\
\text { bogies on both sides of the car). } \\
\text { Signaling: DS-ATC }\end{array}$ \\
\hline
\end{tabular}

Source: Own study

\section{Global SuCCESS OF ERTMS}

ERTMS is the European Committee's Standard System for railway operation in Europe. It was conceptualized, specified and developed by the European Union Agency for Railways (ERA). It was developed as an open standard and all specifications are available for free in the public domain. It is an established standard with a set of specifications that allows different railway suppliers with proven interoperable solutions to supply the same standardized onboard or wayside subsystems. Moreover, an ERTMS wayside subsystem from one railway supplier can safely manage trains fitted with an ERTMS onboard subsystem from another railway supplier. Because of the presence of different ERTMS suppliers and the technical compatibility between components, ERTMS has become a global railway signaling solution and therefore 'fit for purpose' for the coming African Integrated Railway Lines Network.

ERTMS technical specifications for interoperability undergo constant revision by the European Committee to ensure availability of the latest standard that conforms to latest technologies. This constant revision and the public availability of the technical specifications guarantees the credibility of ERTMS as a railway signaling solution, thus making ERTMS a favorable choice.
ERTMS as a standard provides operational and technical interoperability by unifying all the national or 'stand-alone' signaling systems thus opening railway networks to all railway suppliers and operators.

\section{CONCLUSION}

Railway Lines Network development in Africa has obtained a rejuvenated focus with many countries constructing national and even regional railway lines. But while this is happening, the continental ambitions of an integrated and fully interoperable railway lines network seem to be overlooked. This may be due to the lack of collectively adopted rules and guidelines to govern this development. For instance, while rail spacing standards retained by Union of African Railways are $1435 \mathrm{~mm}$ for North Africa, $1067 \mathrm{~mm}$ for South and East Africa, and 1000 $\mathrm{mm}$ for West Africa [5], individual countries continue to develop railway lines with total disregard of this adoption.

With a sense of urgency, the African Union, as previously done by the European Committee, should enact rules on technical standards and operation to guide this development. The rules should make it a legal and mandatory requirement that all new, upgraded or renewed tracks and rolling stock in the African railway lines network adopt a specific signaling train control system, possibly keeping 'legacy' or 'stand-alone' systems for downward compatibility. Specific electrification systems must be agreed upon and adopted by the various countries undertaking railway development. A Homologation and Standardization process should be designed that clearly defines the main technical aspects of both high-speed and conventional lines (signaling and control, power supply, and safety) in order to be certified as fully interoperable. All African countries must adhere to the rules in order to standardize certain aspects of railway operation across Africa.

\section{REFERENCES}

[1] African Union Commission, “Agenda 2063 Framework Document," Addis Ababa, 2015.

[2] A. Deen, "African Integrated High-Speed Railway Network Project (AIHSRNP/HSP)," presented at the $3^{\text {rd }}$ PIDA Week, Swakopmund, Namibia, December 10 - 14, 2017.

[3] Council of the European Union, "Council Directive 96/48/EC on the interoperability of the trans-European high-speed rail system," Official Journal of the European Communities, 1996.

[4] “Africa's first high-speed line inaugurated," Nov. 16, 2018. Accessed on: March 15, 2019. [Online]. Available: https://www.railwaygazette.com/news/news/africa/singleview/view/africas-first-high-speed-line-inaugurated.html

[5] ARU General Secretariat, "Rail Development in Africa: Stakes and Prospects, Objectives and Missions of the African Rail Union (ARU)," presented at the First African Union Conference of African Ministers Responsible for Railway Transport, Brazzaville, Congo, April 10 - 14, 2006.

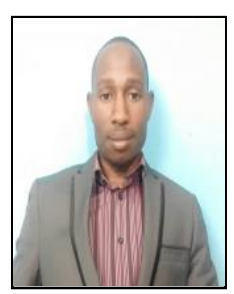

Said N. Rajab was born in Kilifi, Kenya in 1991. He obtained his Bachelor degree (2016) from the Department of Electrical Engineering, University of Nairobi. He is currently a Master student at the African Railway Center of Excellence, Addis Ababa University, Ethiopia. His main interests are signaling and communication for railway systems. His Master thesis deals with RAMS and Life Cycle Costing on railway signaling systems. 